\title{
Prediction of Participation of Undergraduate University Students in a Music and Dance Master's Degree Program
}

\section{Evangelos Bebetsos}

Assoc. Prof., School of Physical Education \& SportScience, Democritus University of Thrace, Komotini, Hellasempempet@phyed.duth.gr

The aim of the study was the investigation of students' attitudes and intention towards their possible participation in a graduate Music and Dance Distance Learning Master's Degree Program. The sample consisted of consisted of 229 undergraduate University students, between the ages of 20 to $63 \mathrm{yrs}$. of age $(M=34.24, S D=10.70)$. More specifically, 134 were students of the Hellenic Open University and 95 were students of the School of Physical Education and Sport Science, of the Democritus University of Thrace. The sample completed the version the "Planned Behavior Theory" questionnaire. Results revealed differences among students of both Universities, between experienced and less experienced ones, and also among age groups. On the contrary, no sex differences in any of the questionnaire's factors were indicated. In conclusion, the findings of this research allow a better understanding of the distance education process, which explains the attitudes and intention(s) of students' participation, and the factors that might influence theirparticular participation.

Key Words: distance learning, attitudes, intention, role identity, attitude strength

\section{INTRODUCTION}

The "Theory of Planned Behavior"is a theory of reasoned decision-making, which describes the type and the process of information during the decision-making process (Ajzen, 2011; Chatzisarantis, et al., 2009). It originated as an expansion of the theory of reasoned action (Ajzen\&Fishbein, 1980), by its inability to interpret behavior in which people do not have full control over the particular behavior (Ajzen, 1991; Ajzen\& Madden, 1986).

Majorrolein the theory ofplanned behaviorplaysthe "intention"of the individual toperform aspecific behavior. Intentions capture the motivational factors that influencebehaviorand reflectthe relative strengthofthe individual'smotivationto engagein thisbehavior (Hagger, et al., 2002).These intentions are mainly theindicatorsofhow hardpeoplearewillingto trytoperformthis specific behavior. As arule of thumbit can be concluded that the strongerthe intentionof an individual to engagein abehavior, the more likelytoimplement that behavior(Ajzen, 1991).It shouldbe noted, however,that the 
intentionmay be expressed in abehavior onlywhen theeventbehaviorisunder the controlof the individual, which does not occur all the time.

Accordingto the theory, there are three independentdeterminantsof intentionthat must be under consideration. Thefirst isthe "attitude" towardsthe behavior,and refersto the degree towhich a personevaluatespositively ornegativelya behavior and general emotionalandcognitiveorientationstowardthat behavior(Ajzen, 1991; Chatzisarantis, et al., 2008; Chatzisarantis, et al., 2009).The secondis"subjectivenorms", which refer to thedegree ofperceivedsocialpressure-influence fromsignificant othersto performor notperform thisspecific behavior(Ajzen, 1991; Chatzisarantis, et al., 2009; Harris \&Hagger, 2007).And the thirdis "perceivedbehavioralcontrol", which refers to theperceivedeaseor difficultyof executionofthat behaviorand is assumed toreflectprevious experienceweresituational obstaclesmay play a crucial role(Ajzen, 1991; Chatzisarantis, et al., 2008, Chatzisarantis, et al., 2009).As Ajzen (1991) stated,the morepositivelydisposedattitudes andsubjectivenormstowards thebehavior andthe greater theperceived control are, the stronger theintention toperform thisbehavior.

Research indicated that two variables have been added to the main model of planned behavior theory to predict behavior (Theodorakis, 1994). These variables are "role identity" that represents a particular social object that represents a dimension of the self, and "attitude strength", a variable that expresses how positive, strong, and important are the attitudes towards a given behavior. Role identity serves as a link between the individual self and society (Callero, 1985). The concept is based on Burke's identity theory (1980) in which an individual's self-concept is organized into a hierarchy of role identities that correspond to one's position in the social structure. These might include being a parent, a spouse, a teacher or an employee (Charng, Piliavin, \&Callero, 1988).

Additionally, in the caseof attitudestowarda behaviorwhich isanybelief that a person has, links his/her behaviorto a specificoutcome orattributesuch asthe costofperforming thisbehavior. Sincethe characteristics oroutcomes associatedwith the behavioralready evaluatedpositively ornegatively, people automatically form an attitude toward the behavior(Ajzen, 1991).As a result of that, peopleprefer and have positive attitudestowardsbehaviors that they believe that willhavethe desiredresults, andnegative attitudesonbehaviors thatthey believe that willhaveundesirableresults. Attitudesare formedthroughtherelationship betweenbehaviorof the certain outcome(behavioral beliefs) and on the subjective value of that outcome itself (Ajzen, 1991; Chatzisarantis\&Hagger, 2005).

To perform a specificbehaviordepends toa great or lesserextenton factorshow dealswith the intentionand motivation of theindividual.These factorscanbe derivedfrom the individual himselfor from theexternal environment. Examples of internalfactorsthat influencebehaviorareskills, abilities, knowledge and adequateplanning, while examplesof external factorsaretime, money, opportunities and dependencybehaviorfrom cooperationwith other people(Ajzen, 1991; Ajzen\& Madden, 1986). 
Investigators have already used the "Theory of Planned Behavior" in order to predict numerous behaviors: intention to participate in sports and physical activities (Godin \&Shephard, 1986), intention of pregnant women to exercise after giving birth (Godin et al., 1989), participation in sports and physical activities (Theodorakis et al, 1995; Theodorakis, 1994). Also, for healthy and unhealthy behaviours (Povey et al., 2000; Armitage\&Conne, 2001; Sheeran et al., 2001), alcohol use (Rise \&Wilhelmson, 1998), safer sex (Sheeran et al., 1999), smoking, exercising, and eating-habit domains (Sheeran\&Orbell, 2000; Bebetsos et al., 2002; Bebetsos et al., 2003; Bebetsos et al., 2014), moral judgment (Bebetsos \&Konstantoulas, 2006), special education (Bebetsos et al., 2013), and distant education (Goulimaris et al., 2008).

A form of behavior that can be studied with the use of the "Theory of Planned Behavior" is the participation of students in a music and dance distance education master program. The distinction between art and science, the connection of dancing with well-being, and the satisfaction of psychological needs (Goulimariset al., 2014; Goulimaris, 2015) as well as the perception that dance is a pleasant, light activity, deprived it from a more scientific approach and study.

In Greece, in the University level-education there is no dance department, school or an educational program exclusively dealing with dance. The needs concerning this specific subject field are partially covered by the program offered by the Hellenic National School of Dance and by numerous private dance schools/clubs.

A significant advancement for the study of dance on a University level has been the creation of Schoolsof Physical Education and Sport Science which gives students the opportunity to specialize in Hellenic dances (Serbezis, 1995). It must be mentioned that undergraduate studentswho attend this line of studies are taught with the use of the "traditionalmethod", which takes place within the contents of a classroom.Even,the overall curriculumis oriented towards the acquisition ofmotor skills in combination with practice-courses (Goulimaris, 1998; Kardaris, 2002; Koutsoumbas, 1997; Lantzos, 2003; Lykesas, 2002; Serbezis, 1995; Tyrovola, 1994; Zografou, 1989).

The only course in education concerning Hellenic dance and music, which is taught with the "distance education method", is carried out by the Hellenic Open University and it is an option for the fourth year (senior) students attending "Hellenic Civilization" (Bebetsos \&Goulimaris, 2014). The study of dance acquires new potentials with the adoption of innovative methods of education, like distance education and the use of new technologies (Papastergiou, Antoniou, \& Apostolou, 2011). Nonetheless, the nature of dancei.e. the increasing demands for the acquisition of new kinetic dexterities and the need for a personal guidance of the trainee creates certain difficulties in relation to the distance education method (Goulimaris et al., 2008).Asaresult, thestudies' programisonlybasedonthetheoreticalbackgroundof music and dance excluding any motor skill acquisition.

Research Aim

Therefore, the study was conducted in an attempt: 
(i) To investigate whether the application of the Theory ofPlanned Behavior can predict future intention specifically onattendance of a Master's Program on Dance and Music.

(ii) To identify the variables that might differentiate the sample.

\section{METHOD}

\section{Study Samples}

The sample consisted of 229 undergraduate University students, between the ages of 20 to 63 yrs. of age $(M=34.24, S D=10.70)$. More specifically, 134 were students of the Hellenic Open University who participated in the course of "Arts II: Overview of Music and Dance"and 95 were studentsof the School of Physical Education and Sport Science, of the Democritus University of Thrace, with Major in Dance Studies (Table 1).

Table 1:Demographic characteristics of the sample.

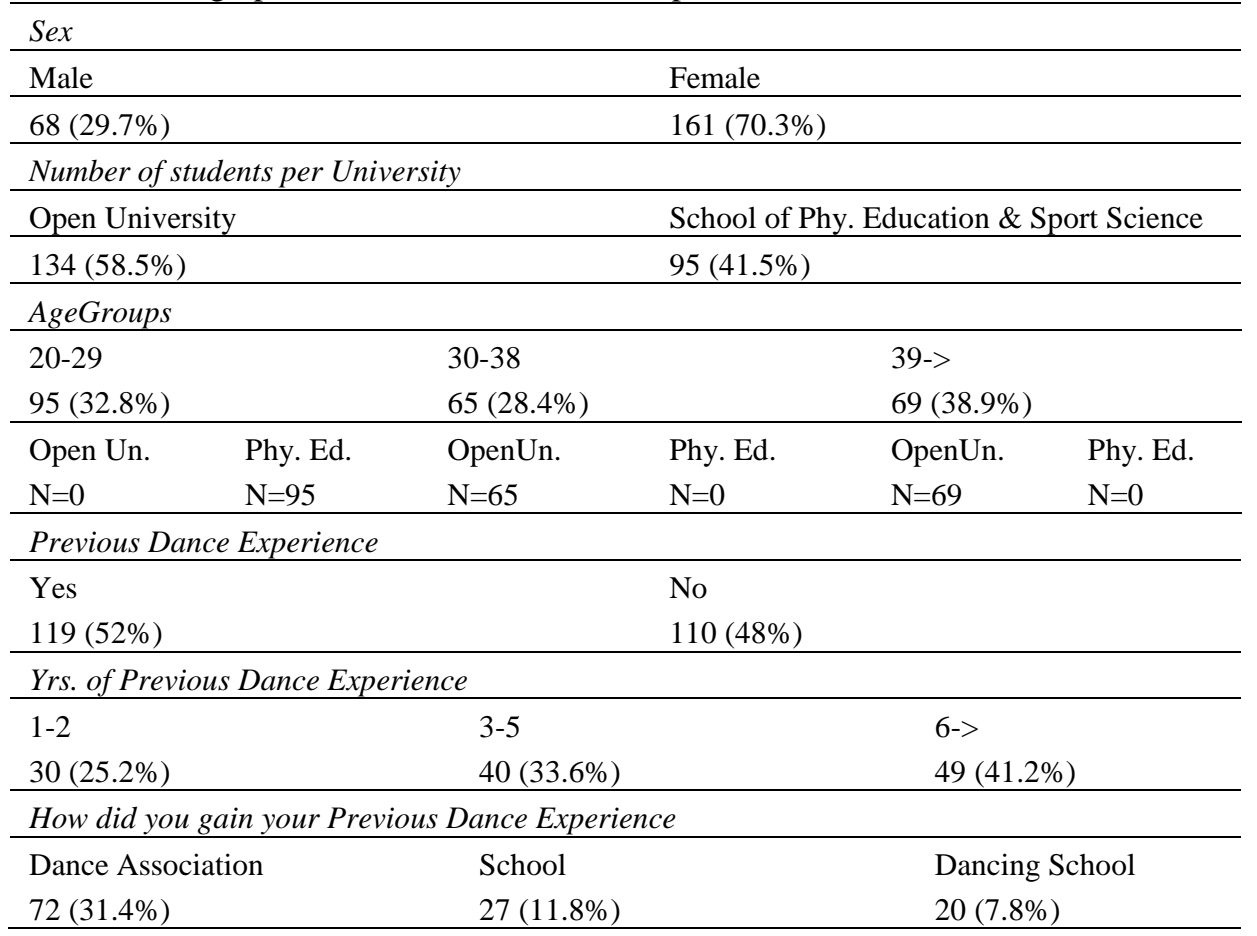

\section{Questionnaire}

The sample completed the revised version the "Planned Behavior Theory" questionnaire (Ajzen\& Madden, 1986; Theodorakis, 1994; Bebetsos \&Konstantoulas, 2006). The questionnaire included: 
a) Five questions on "Attitudes" with responses rated on a 7-point Likert-type scale, on five bipolar adjectives "For me to participate regularly next academic year in a Music and Dance distant education Master's Program, is..." $7=\operatorname{good}$ to $1=$ bad, $1=$ foolish to $7=$ smart, $7=$ useful to 1 =unuseful, $7=$ pleasant to $1=$ unpleasant, and $1=$ unhealthy to $7=$ healthy.

b) Three questions on "Intention" were responses to the first question rated on a 7-point Likert-type scale from $1=$ very unlikely to $7=$ very likely "I intend to participate regularly next year in a Music and Dance distant education Master's Program”, while a 7-point Likert-type scale with endpoints labeled 1=definitely no to 7=definitely yes, was used for the other two questions "I will try to participate regularly next year in a Greek Music and Dance Master's Program".

c) Four questions on "Role Identity" with responses rated on 7-point Likert-type scales from $1=$ strongly disagree to $7=$ strongly agree "Generally I'm the type of a person who participate regularly next year in a Music and Dance distant education Master's Program" (Theodorakis, 1994), and,

d) Four questions on "Attitude Strength" were responses to the first question rated on a 7-point Likert-type scale from $1=$ not at all to $7=$ very much so "How interesting is it for you participate regularly next year in a Music and Dance distant education Master's Program?", while a 7-point Likert-type scale with endpoints labeled 1=strongly disagree to $7=$ strongly agree was used for the second question "With the academic knowledge that I have, I believe that I must participate regularly next year in a Music and Dance distant education Master's Program", next was a 7-point Likert-type scale with endpoints labeled $1=$ not at all to $7=$ very much so that was used for the third question "For me to participate regularly next year in a Music and Dance distant education Master's Program is very important", and finally a 7-point Likert-type scale with endpoints labeled $1=$ not at all to $7=$ very much so, was used for the forth question "Do you find it interesting to participate regularly next year in a Music and Dance distant education Master's Program?".

The questionnaire also included questions related to sex, age, school, previous dance related experience, years of previous experience, and were it was acquired.

The method chosen to conduct the research was that of self-completed questionnaire. Researcher informed all subjects that their participation was completely voluntary and the individual responses would be held in strict confidence. The questionnaire was handed out during a class meeting with the presence of teacher/instructor.

\section{FINDINGS}

\section{Reliability Analysis}

The analysis showed that $\alpha$ Cronbach coefficient was .87 for "Attitudes", .82 for "Intention", .86 for "Role Identity", and .95 for "Attitude Strength". The results indicated that the questions in all four factors had a very satisfying internal cohesion. 
One-way Anova analysis was conducted in order to investigate any possible differences between the two "Universities' students". The analysis revealed statistical significant differences in the following factors (Table 2):

1) For the factor of "Intention" $F_{(1,214)}=3.77, p<.05$. The $1^{\text {st }}$ group (students of Hellenic Open University) had the highest score $(M=3.67, S D=1.78)$, followed by the $2^{\text {nd }}$ group (students ofSchool of Physical Education and Sport Science) with the lowest score $(M=3.00, S D=1.71)$.

2) For the factor of "Role Identity" $F_{(1,216)}=4.80, p<.01$. The $1^{\text {st }}$ group (students of Hellenic Open University) had the highest score $(M=4.46, S D=1.80)$, followed by the $2^{\text {nd }}$ group (students ofSchool of Physical Education and Sport Science) with the lowest score $(M=3.69, S D=1.67)$.

3 ) For the factor of "Attitude Strength" $F_{(1,206)}=3.72, p<.05$. The $1^{\text {st }}$ group (students of Hellenic Open University) had the highest score $(M=4.30, S D=1.60)$, followed by the $2^{\text {nd }}$ group (students of School of Physical Education and Sport Science) with the lowest score $(M=3.62, S D=1.72)$.

Table 2. Students' differences

\begin{tabular}{lllllll}
\hline & Intention & \multicolumn{3}{c}{ Role Identity } & \multicolumn{2}{c}{ Attitude Strength } \\
\cline { 2 - 7 } & $M$ & $S D$ & $M$ & $S D$ & $M$ & $S D$ \\
\hline Open University & 3.67 & 1.78 & 4.46 & 1.80 & 4.30 & 1.60 \\
\hline School of Phy. Ed. & 3.00 & 1.71 & 3.69 & 1.67 & 3.62 & 1.72 \\
\hline
\end{tabular}

One-way Anova analysis was conducted in order to investigate any possible differencesbetween "age groups". The analysis revealed statistical significant differences in the following factors (Table 3):

1) For the factor of "Intention" $\left.F_{(1,214)}=6.53, p<.05\right)$. More specifically, the post hoc multiple comparisons Bonferonni test indicated the differences between the $1^{\text {st }}$ group with the lowest score $(M=4.7, S D=1.87)$, with both the $2^{\text {nd }}(\mathrm{M}=5.04, \mathrm{SD}=.97)$, and the $3^{\text {rd }}$ with the highest score $(\mathrm{M}=5.54, \mathrm{SD}=.71)$.

2) For the factor of "Attitude Strength" $\left.F_{(1,214)}=6.32, \mathrm{p}<.05\right)$. More specifically, the post hoc multiple comparisons Bonferonni test indicated the differences between the $1^{\text {st }}$ group with the lowest score $(M=3.7, S D=1.08)$, with both the $2^{\text {nd }}(M=4.1, S D=.73)$, and the $3^{\text {rd }}$ with the highest score $(M=4.4, S D=.60)$.

Table 3. Age Groups' differences

\begin{tabular}{lllll}
\hline & \multicolumn{2}{l}{ Intention } & \multicolumn{2}{l}{ Attitude Strength } \\
\cline { 2 - 5 } & $M$ & $S D$ & $M$ & $S D$ \\
& 4.7 & 1.87 & 3.7 & 1.08 \\
\hline $2^{\text {st }}$ age group & 5.04 & .97 & 4.1 & .73 \\
\hline $3^{\text {rd }}$ age group & 5.54 & .71 & 4.4 & .60 \\
\hline
\end{tabular}

Univariate analyses were conducted in order to find any type of gender and/or previous dance experience related differences. The analyses revealed statistically significant differences only in the variable of previous dance experience (Table 4): 
1) For the factor "Intention" $\left(F_{1.215}=5.19 ; p<0.05\right)$. More specifically, the post hoc multiple comparisons Bonferonni test indicated the differences between the experienced group ( $M=3.51, S D=.19)$, with the notexperienced one $(M=2.95, S D=.18)$.

2) For the factor "Self -Identity" $\left(F_{1.217}=13.52 ; p<0.001\right)$. More specifically, the post hoc multiple comparisons Bonferonni test indicated the differences between the experienced group $(M=4.42, S D=.18)$, with the not experienced one $(M=3.52, S D=.17)$.

$3)$ For the factor "Attitude Strength" $\left(F_{1.207}=7.66 ; p<0.01\right)$. More specifically, the post hoc multiple comparisons Bonferonni test indicated the differences between the experienced group $(M=4.20, S D=.18)$, with the not experienced one $(M=3.51, S D=.17)$.

Table 4. Previous Dance Experience differences

\begin{tabular}{lllllll}
\hline & Intention & \multicolumn{2}{c}{ Self-Identity } & \multicolumn{2}{c}{ Attitude Strength } \\
\cline { 2 - 7 } & $M$ & $S D$ & $M$ & $S D$ & $M$ & $S D$ \\
Experienced & 3.51 & .19 & 4.42 & .18 & 4.20 & .18 \\
\hline Not experienced & 2.95 & .18 & 3.52 & .17 & 3.51 & .17 \\
\hline
\end{tabular}

No sex differences were indicted in any factor of the questionnaire.

\section{DISCUSSION}

The aim of the study was the investigation of intention of undergraduate University students in order to attend a Master's Degree Music and Dance Program. To the investigator's knowledge, few similar studies have been conducted on the specific topic either in physical education or other courses. Therefore, discussion and conclusions from the present study reflect a first attempt to interpret the relation of attitudes, intentions and behaviors of undergraduate students towards the participation in a Masters’ Degree Music and Dance Program.

To begin with, the results support the validity of planned behavior model in the education domain. That is, attitudes, self-identity and attitude contributed to intentions regarding the participation in a post graduate Music and Dance Program.More specifically, students who attended Open University have greater scores than the students of School of Physical Education, in all 3 factors. These scores underline the greater experience that Open University students had were the University curriculum indicates that the $4^{\text {th }}$ year (senior) courses are all conducted with the use of distance education method. As past research illustrated students who are more familiar with this specific education procedure, express more positive attitudes towards their inclusion in a distance learning Master's Program (Antoniou et al., 2009).

Results also revealed age differences. Open University students (groups 2 \& 3), who were generally older in age (Table 1),illustrated greater scores in the factors of "intention" and "attitude strength" than their colleagues of the School of Physical Education (group 1). Older studies in the broader academic field of the tertiary education support that one of the basic factors which increase the general behavior of students in such institutes are the chances which are offered to them for personal, academic and professional development (Aldemir\&Gulcan, 2004; Navarro et al., 2005).

Accordingly, the students with previous dance experience scored higher on the factors of "intention", "self-identity" and "attitude strength" (Table 4). They consider their 
participation in a distance education master program on music and dance as a part of their identity and they feel more secure about participating. This point of view agrees with previous results (Goulimaris et al., 2008) and confirms the notion that knowledge of the subject and increased dance ability due to previous experience, contribute to the students' capability and certainty about participating in corresponding educational programs. Similar results were found in other research concerning athletic behavior (Bebetsos et al., 2004), special education (Batsiou et al., 2006) and computer use (Bebetsos et al., 2007).

Finally, no difference due to sex existed among the examined factors. Regarding the relationship between dance and sexes, it is well known a general perception that dance is more of a "woman's thing", meaning that it suits the female idiosyncrasy and character more than the male. However, this idea is not supported by the present research, which is not a totally unexpected finding as a part of the research sample was composed of students of Physical Education specializing in dance. Previous research indicated similar results (Goulimaris et al., 2008; Filippou et al., 2014).

\section{Implication of the study}

The impact of the study proved the necessity of improving teaching methods within the University level education on teaching specifically music and dance. Very limited studies were conducted in Greece towards that direction, so educating researchers on students' attitudes and intentions might improve the overall education process.

\section{Limitation and Recommended Future Studies}

For future studies it is recommended the use of this specific theory and similar ones in order to investigate possible intentions of students' participation in any new Graduate Programs (Master and Ph.D.) of different Universities, even on combining these programs.

A possible limitation of the study might be that the sample consisted mainly by female students. Addressing the same study on students from different cultures might derive interesting results.

\section{CONCLUSION}

In conclusion, this study and its results are considered as positive and encouraging towards the development of a distance learning Master's Degree Program, in Greece. A further investigation as well as the research for other aspects that might influence this attempt such as economic status, quality of studies, institute's quality, and instructor's quality, is considered to be necessary.

\section{REFERENCES}

Ajzen, I. (1991). The theory of planned behavior.Organizational Behavior and Human Decision Processes, 50: 179-211.

Ajzen, I. (2011). The theory of planned behaviour: Reactions and reflections. Psychology and Health, 26(9): 1113-1127.

Ajzen, I., \&Fishbein, M. (1980).Understanding attitudes and predicting social behavior. Englewood Cliffs, NJ: Prentice-Hall. 
Ajzen, I., \& Madden, T. J. (1986). Predictions of goal-directed behavior: Attitudes, intentions and perceived behavioral control. Journal of Experimental Social Psychology, 22: 453-457.

Aldemir, C., \&Gulcan, Y. (2004). Students Satisfaction in Higher Education: A Turkish Case. Higher Education Management and Policy, 16(2): 109-122.

Armitage, C. J., \& Conner, M. (2000). Social cognition models and health behaviour: A structured review. Psychology \& Health, 15: 173-189.

Antoniou, P., et al., (2009). Teaching physical education issues in the compulsory education using digital learning environments. In A. Méndez-Vilas, et al., (Eds.), Research, Reflections and Innovations in Integrating ICT in Education. Badajoz, Spain: Formatex. (pp. 819-824).

Batsiou, S., et al., (2006).Attitudes and intention of Greek and Cypriot primary education teachers towards teaching pupils with special educational needs in mainstream schools.International Journal of Inclusive Education, 12: 201-219.

Bebetsos, E., et al., (2004). Knowledge and information in prediction of intention to play badminton.Perceptual and Motor Skills, 98: 1210-1218.

Bebetsos, E., et al.,(2002). Physically active students' intentions and self-efficacy towards healthy eating.Psychological Reports,92: 485-495.

Bebetsos, E., et al., (2013).Relationship among Students' Attitudes, Intentions and Behaviors towards the Inclusion of Peers with Disabilities, in Mainstream Physical Education Classes.International Electronic Journal of Elementary Education, 5(3): 233-248.

Bebetsos, E. \&Goulimaris, D. (2014).Personal outcome and leadership as defining factors of satisfaction in the context of the course "Arts II: Overview of Greek Music and Dance" of the Hellenic Open University. Turkish Online Journal of Distance Education, 15(2): 12-24.

Bebetsos, E., \&Konstantoulas, D. (2006). Contact sports, moralfunctioningandplanned behaviour theory. PerceptualandMotorSkills, 103:131-144.

Bebetsos, E., Kouli, O., \& Antoniou, P. (2007). Attitudes and Behaviors of University PE Students Towards the Use of Computers. International Journal of Computer Science in Sport,6(1): 55-63.

Bebetsos, E., et al., (2003).Universitystudents' attitudesandbehaviourstowardssmokingand exercise.European Journal of Physical Education, 8: 29-51.

Bebetsos, E., et al., (2014). Health Related Behaviors among Hellenic Naval Academy Cadets. Procedia - Social and Behavioral Sciences, 152: 813-818.

Burke, P. J. (1980). Measurement requirements from an interactionist perspective.Social Psychology Quarterly, 43: 18-29.

Callero, P. L. (1985). Role-identity salience.Social Psychology Quarterly, 48: 203-215. 
Charng, H. W., et al., (1988). Role identity and reasoned action in the prediction of repeated behavior.Social Psychology Quarterly, 51: 303-317.

Chatzisarantis, N. L. D., \&Hagger, M. (2005). Effects of a brief intervention based on the theory of planned behavior on leisure-time physical activity participation. Journal of Sport and Exercise Psychology, 27: 470-487.

Chatzisarantis, N., et al., (2008). Using the construct of perceived autonomy support to understand social influence within the theory of planned behavior.Psychology of Sport and Exercise,9: 27-44.

Chatzisarantis, N., et al., (2009). The Effects of Social Identity and Perceived Autonomy Support on Health Behaviour Within the Theory of Planned Behaviour. Current Psychology, 28(1): 55-68.

Filippou, F., Bebetsos, E., Vernadakis, N., Zetou, E., \&Derri, V. (2014). The effect of an interdisciplinary Greek traditional dance, music, and sociology program on male and female students' anxiety.Procedia - Social and Behavioral Sciences, 152: 1237-1241.

Goulimaris, D. (1998). Study on the organizational structure and operation of traditional dance clubs in Greece and Belgium: The European dimension (in Greek). Unpublished Doctoral Dissertation, Democritus University of Thrace, Greece.

Goulimaris, D. (2015). The relation between distance education students' motivation and satisfaction. Turkish Online Journal of Distance Education, 16(2), 13-27.

Goulimaris, D., et al., (2008).The organization of a distance postgraduate dance program and the participation of students specializing in dance.Turkish Online Journal of Distance Education, 9(3): 59-73.

Goulimaris, D., et al., (2014).Relationships between basic psychological needs andpsychologicalwell-beingin recreationaldance activities.Journal of Physical Education and Sport, 14(2): 277-284.

Goulimaris, D., et al., (2013). Hellenic Open University Dance Studies and the role of "Planned Behavior" on students' participation on organized distant learning post graduate studies.Open Education - The Journal for Open and Distance Education and Educational Technology, 9(1): 106-119.

Hagger, M. S., et al., (2002). The influence of autonomous and controlling motives on physical activity intentions within the theory of planned behaviour. British Journal of Health Psychology, 7: 283-297.

Kardaris, D. (2002). Dancing in Zakynthos through political and social history (in Greek).Unpublished doctoral dissertation, National and KapodistrianUniversity of Athens, Greece.

Koutsouba, M. (1997).Plurality in motion: Dance and cultural identity on the Greek Ionian island of Lefkada. Unpublished doctoral dissertation, University of London, UK.

Lantzos, V. (2003). The functionality of dance in the cycle of anastenarismou in Kostiof Sozopoli province (in Greek).Unpublished doctoral dissertation, National and KapodistrianUniversity of Athens, Greece. 
Lykesas, G. (2002). The teaching of Greek traditional dances in primary education by the musical education method (in Greek).Unpublished doctoral dissertation, Aristotle University of Thessaloniki, Greece.

Navarro, M. M., et al., (2005). A New Management Element for Universities: Satisfaction with the offered courses. International Journal of Educational Management, 19(6): 505-526.

Papastergiou, M., et al., (2011). Effects of student participation in an online learning community on environmental education: a Greek case study. Technology, Pedagogy and Education 20(2): 127-142.

Povey, R., et al., (2000). Application of the theory of planned behaviour to two dietary behaviours: roles of perceived control and self- efficacy. British Journal of Social Psychology, 5, 121-139.

Rise, J., \&Wilhelmson, B. U. (1998). Prediction of adolescents' intention not to drink alcohol: Theory of planned behaviour. American Journal of Health Behaviour, 22: 206217.

Serbezis, V. (1995). A comparative study of Greek traditional dance teaching methods for children aged 9-11 (in Greek). Unpublished doctoral dissertation, Democritus University of Thrace, Greece.

Sheeran, P., et al., (1999). Psychosocial correlates of heterosexual condom use: a metaanalysis. Psychological Bulletin, 125(1): 90-132.

Sheeran, P., et al., (2001). Can the theory of planned behavior explain patterns of health behavior change? Health psychology, 20(1): 12-19.

Sheeran, P., \& Orbell, S. (2000). Self-schemas and the theory of planned behaviour. European journal of social psychology, 30: 533-550.

Sutton, S., et al., (1999).a comparative test of the theory of reasoned action and the theory of planned behavior in the prediction of condom use intentions in a national sample of english young people. Health psychology, 18(1): 72-81.

Theodorakis, Y. (1994). Planned behavior, attitude strength, self-identity, and the prediction of exercise behavior.The Sport Psychologist, 8: 149-165.

Theodorakis, Y., et al., (1995). Attitudes toward teaching individuals with disabilities: application of planned behavior theory. Adapted Physical Activity Quarterly, 12: 151160.

Tyrovola, V. (1994). O "chorosstatria": Structural morphological and typological approach of the form (in Greek). Unpublished doctoral dissertation, National and KapodistrianUniversity of Athens, Greece.

Zografou, M. (1989). Folklore - anthropological approach of sera dance. Unpublished doctoral dissertation, University of Ioannina, Greece. 


\section{Turkish Abstract}

\section{Lisans Öğrencilerinin Müzik ve Dans Yükseklisans Programına Katılma Durumları}

$\mathrm{Bu}$ çalışmanın amacı ögrencilerin Müzik ve Dans Yükseklisans Programına muhtemel katılmalarındaki tutum ve niyetlerini incelemektir. Örneklem 20-63 yaş arası 299 lisans öğrencisinden oluşmaktadır. 134 öğrenci Hellenic Open University öğrencisiyken, 95 öğrenci ise School of Physical Education and Sport Science, of the Democritus University of Thrace öğrencisidir. Örneklem "Planlanmış Davranış Teorisi" anketini doldurmuşlardır. Sonuçlar deneyimli olmanın ve yaşın farklılıklara sebep olduğunu gösterirken, cinsiyetin bir etkisinin olmadığını ortaya koymuştur. Sonuç olarak çalışmanın bulguları uzaktan eğitimin işleyişini anlamada ve katılımı belirleyen faktörleri ortaya çıkarmada ipuçları ortaya çıkarmıştır.

Anahtar Kelimeler: uzaktan öğretim, tutum, niyet, rol kimliği, tutum gücü

\section{French Abstract}

Prédiction de Participation d'Étudiants Universitaires En licence dans une Musique et un Programme de Master de Danse

Le but de l'étude était l'enquête des attitudes des étudiants et l'intention vers leur participation possible dans une Musique diplômée et un Programme de Master d'Enseignement à distance de Danse. L'échantillon a consisté en consisté en 229 étudiants Universitaires en licence, entre les âges de 20 à 63 ans. D'âge $(\mathrm{M}=34.24, \mathrm{SD}=10.70)$. Plus spécifiquement, 134 étaient les étudiants de l'Université Ouverte hellénique et 95 étaient les étudiants de l'École de Culture physique et la Science Sportive, de l'Université Democritus de la Thrace. L'échantillon a complété(achevé) la version "la Théorie de Comportement Planifiée" le questionnaire. Les résultats ont révélé des différences parmi les étudiants des deux Universités, entre des expérimentés et moins expérimentés et aussi parmi des tranches d'âge. Au contraire, aucune différence sexuelle de n'importe lequel des facteurs du questionnaire n'a été indiquée. Pour conclure, les découvertes de cette recherche permettent une meilleure compréhension du processus de formation à distance, qui explique les attitudes et l'intention(s) de la participation des étudiants et les facteurs qui pourraient influencer la participation theirparticular.

Mots-clés: enseignement à distance, attitudes, intention, identité de rôle, force d'attitude

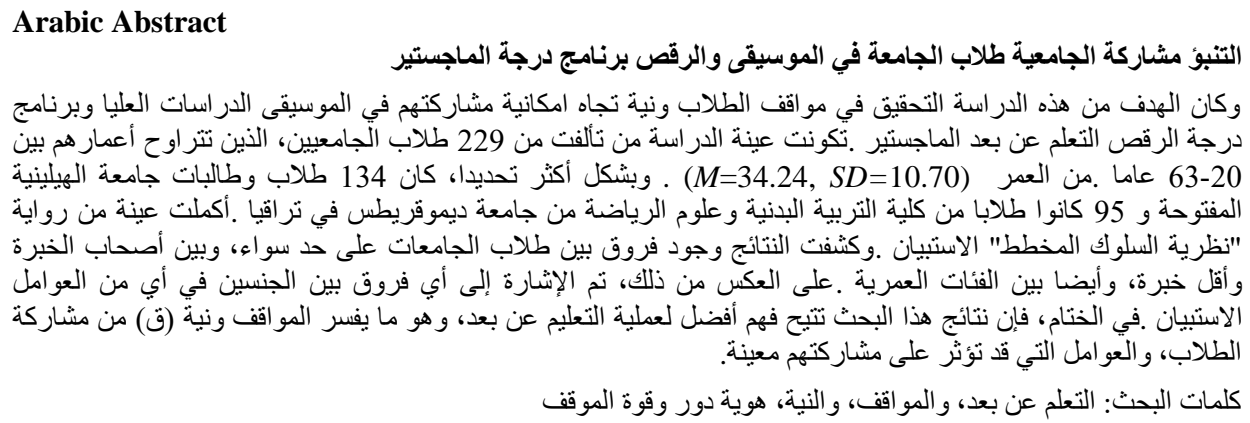

